$9(1)(2020) 48-52$
Indonesian Journal of Early Childhood
Education Studies

\title{
Implementation of Children Nutrition Meeting Through Healthy Eating Program
}

\author{
Wafa Aerin $\bowtie$, Muqowim Muqowim \\ DOI: http://dx.doi.org/10.15294/ijeces.v9i1.38951 \\ Universitas Islam Negeri Sunan Kalijaga Yogyakarta, Indonesia
}

\section{History Article \\ Submitted 9 April 2020 Revised 23 May 2020 Accepted 4 June 2020}

\section{Keywords}

Children; Fulfillment of Nutrition; Healthy Eating Programs

\begin{abstract}
Growth and development in children is greatly influenced by the intake of nutrients in food. During the period of growth and development, the provision of good nutrition is not always carried out perfectly. One of the influencing factors is the level of parental knowledge and children's preference on fast food. If feeding is always not in accordance with the needs of children, it will cause developmental problems in children. One of the efforts made to overcome these problems is a healthy eating program. This research was conducted with the aim to determine the results of nutrition fulfillment in early childhood through a healthy eating program. This research uses descriptive qualitative research methods. Research location in Al-Isyad Al-Islamiyyah Purwokerto Kindergarten. With research subjects include, teachers, Al-Irsyad Al-Islamiyyah Purwokerto Kindergarten students, parents, and school principals. Data obtained through observation, interviews, and documentation. The results of this study describe the implementation of the fulfillment of children's nutrition through a healthy eating program implemented at Al Irsyad Al Islamiyyah Purwokerto Kindergarten, this study also shows good menu variations in accordance with the nutritional needs of early childhood every day in healthy eating programs prepared by nutritionists, so as to improve nutritional status in children.
\end{abstract}

\section{How to Cite}

Aerin, W., \& Muqowim, M. (2020). Implementation of Children Nutrition Meeting Through Healthy Eating Program. Indonesian Journal of Early Childhood Education Studies, 9(1), 48-52. 


\section{INTRODUCTION}

The quality of the nation in the future is determined by the quality of today's children. The optimal development of school-age children depends on providing nutrition with good quality and quantity. During the growth and development of the provision of nutrition or food intake in children can not always be carried out perfectly. Problems often arise, especially in giving food that is not true and deviant. These deviations cause interference with many organs and body systems of children. Foodborne diseases are a major public health problem in many countries. This disease is not considered a serious disease, so often less attention (Lestari, 2012).

The nutritional needs of children are the needs of an estimated amount sufficient to maintain general health. Children's nutrition is needed according to the needs of age, sex, body weight, and TB (height). From here good nutritional status will be seen from the intake received by early childhood (Rusilanti, et al, 2015).

The Department of Nutrition and Public Health FKMUI explained that in 1992 an international nutrition congress was held in Rome that discussed the importance of balanced nutrition as an effort to produce quality human resources. One of the recommendations of the congress is the advice of each country to develop a General Guidelines for Balanced Nutrition (PUGS). PUGS in Indonesia was first introduced in Widyakarya Food and Nutrition V (1993), which basically further refined the slogan of four healthy five perfect. In 2011 PUGS has developed into a Balanced Nutrition Tumpeng (Lestari, 2012).

The nutrition a child receives through daily food consumption plays an important role in the child's life. Socio-economic conditions are one of the important factors influencing status nutrition. If the socioeconomic condition is good, then the nutritional status hopefully the better (Putri, 2015). Food is a basic need for human life. Foods consumed are various types with various processing methods. Children's eating patterns depend on the preparation of the menu, a child has an appetite formed from the habits around him.

In forming healthy eating patterns there are three main supporting factors namely parents, children, and the environment (including the school environment). However, at this time healthy eating patterns have begun to be neglected, with the many busy parents who prefer practical food (junk food), snacks at the seller, parents are often not aware of the food content is dangerous or not, and the rise of food advertisements on TV that will affect healthy eating patterns for children (Rusilanti, 2015).

Habits of children consuming instant food have an impact on the dislike of children consuming vegetables or children have a tendency to consume certain foods. This is not the only reason why children find it difficult to eat vegetables. One of them is because his parents are too forced the child to eat vegetables (Haryanto, 2018).

The composition of children's food that is not in accordance with the balanced nutritional composition, one of which is consumption of vegetables (Candrawati, 2014). Even though vegetables are really needed for children's growth and development in fulfilling nutrition. In addition, the loss of a firm attitude from parents who always obey the wishes of children, citing fear that children do not want to eat. Parents usually prepare foods according to the child's favorite such as fried chicken, nuggets, and other fried foods.

Vegetables function as body regulators, contain vitamins and minerals, have a high water content, are a source of dietary fiber and balance the acid-base levels in the body (Rozaline \& Sekarindah, 2006). Vegetables also function to reduce chronic disease in the body (Hung et al, 2004). The reason why children have difficulty eating vegetables is that children are not accustomed to eating vegetables. Children can become disliked vegetables because parents are not accustomed to giving vegetables as a menu every day. Many parents ignore the provision of vegetables to their children and focus more on foods such as meat, formula milk or other foods that can make their children fat. Though eating vegetables is also very important for the growth and development of early childhood (Haryanto, 2018).

From here we must maximize the fulfillment of good nutrition so that good nutrition can meet the aspects of development and the body in children. Food consumed by children is very dependent on what is provided by parents, the availability of healthy food is defined as the presence or absence of fruits and vegetables in the house, both in the type and quantity (Wyse et al, 2011). Providing healthy food is also very important for physical and child growth because healthy food has adequate nutrition for the body of an early age child. Nutrition obtained from food is the main source to fulfill optimal growth and development so that it can achieve complete health (Hardiansyah, 2017).

One of them is balanced nutrition in schools that play an important role for health, schools not only play a role as education for children. This school's role is to sensitize children and parents 
with healthy eating programs in schools.

One of the schools that conducts healthy eating programs developed at Al-Irsyad Al-Islamiyyah Purwokerto Kindergarten in fulfilling children's nutrition is to introduce healthy foods such as vegetables, fruits, four healthy five perfect, so that later children will get to know healthy food from an early age. Through this program children love healthy food more than junk food without prohibiting it, and children are also accustomed to vegetables.

In the healthy eating program at Al-Irsyad Al-Islamiyyah Purwokerto Kindergarten at four healthy five perfect there is a difference with four healthy five perfect in general. Five perfect here replaced with mineral water because not all children can drink milk, there are also children who are allergic to milk. Therefore, these five perfect ones are replaced with safer mineral water and all children are suitable.

Al-Irsyad Al-Islamiyyah Purwokerto Kindergarten in fulfilling children's nutrition through a healthy eating program is carried out every Monday to Saturday with a different menu. This healthy eating program aims first, the child knows a variety of healthy foods. Second, so that children are more familiar with a variety of vegetables, fruits, and other healthy foods. Third, provide experiences for children to enjoy balanced nutrition, balanced nutrition consisting of carbohydrate, fat, vitamin, protein, and mineral intake, and fourth, children feel together with their friends.

This healthy eating program is not just eating together but holding a cooking day. This cooking day is aimed at children to feel more from how to make it, so that they are invited once a month. See firsthand the ingredients of cooking, provide a stimulus so that children are more accustomed to making their own food, give confidence to children that children can do it, give confidence that vegetables, fruits, etc. that taste good, delicious, and not like what children think about it.

The implementation of a healthy eating program at Al-Irsyad Al-Islamiyyah Purwokerto Kindergarten is a very wise action, in addition to meeting nutritional needs, a healthy eating program is a way to avoid snacks that are not necessarily healthy. The rise of the use of hazardous chemicals in snacks, such as dyes, flavorings to preservatives need to be aware of. One way to avoid unhealthy snacks with a healthy eating program that is done every day (Rusilanti, 2015).

In this article will discuss the implementation of the fulfillment of children's nutrition through healthy eating programs at Al Irsyad Al Islamiyyah Purwokerto Kindergarten. The aim of this reseach is to determine the results of nutrition fulfillment in early childhood through a healthy eating program.

\section{METHOD}

This type of research is field research (Filed Research). This research is classified as a qualitative descriptive study (Moleong, 2013). Data collection techniques in this study used observation, interviews, and documentation. Furthermore, the data that has been obtained is analyzed using the miles and hubermans analysis method (Emzir, 2010).

\section{RESULT AND DISCUSSION}

In accordance with the Vision and Mission of Al Irsyad Al Islamiyyah Purwokerto Kindergarten, which is to produce a generation that is pious, healthy, intelligent, and useful. As where the healthy understanding according to the Basic Health Law No. 9 of 1960, Chapter 1 Article 2 is a feeling that includes physical (physical), spiritual (mental), and social health, and not only being free from illness, disability, and weakness. The definition of healthy is in line with the definition of healthy according to the World Health Organization (WHO) in 1975 as follows: Health is a condition that is free from all types of diseases, both physical, mental, and social.

Meanwhile, to realize healthy, it is not enough to only provide vitamins. Healthy in its planting requires direct practice with children, it needs to be accustomed to doing a healthy diet. One of the anxiety of parents in children related to healthy eating patterns is that children find it difficult to eat every day three times a day and children prefer to consume unhealthy snacks / snacks. Even though the child's body needs nutritious food so it is not easily hurt, weak, and stronger. At kindergarten age, children can already choose the food they like, so the pattern that parents must establish is to instill eating habits with good nutrition from an early age. Good food is fruit and vegetables. Koui and Jago (2008) explains that the availability of fruits and vegetables at home is related to the level of food consumption in children

Most parents tend to follow the wishes and desires of children, so children tend to prefer foods that are less healthy or completely instant and do not like vegetables at all. If this is left un- 
checked, it will have an impact on the nutritional status of the child himself. To support the fulfillment of the nutritional status of children in $\mathrm{Al}$ Irsyad Al Islamiyyah Purwokerto Kindergarten, in 2003 a program called healthy eating was organized.

In 2003, the healthy eating program at $\mathrm{Al}$ Irsyad Al Islamiyyah Purwokerto Kindergarten ran once a week on Saturdays. This program continued to run smoothly until 2015. Because it was considered to have a positive impact on children's interest in vegetables, and was based on inputs from student guardians, as well as on fulfilling children's nutrition. So in 2015 this healthy eating program began every day.

Analysis based on the book titled Ruslianti's Nutrition and Children's Health by Ruslianti (2015) explained that health is very important for the growth and development between mental and physical development. Nutrition is very important for the growth and development of children, especially at the age of 1-3 years (U1fah et al, 2018). Nutrition is one of determining health. There are several components in nutrition that are needed by our body namely, carbohydrates, proteins, fats, vitamins, minerals and water.

Based on interviews with the head of the Al Irsyad Al Islamiyyah Purwokerto Kindergarten, one of the things that strongly encourages this program to be carried out every day is to avoid hawking children while at school. Many children who before the healthy eating program were provided with an allowance by their parents and were used to buy snacks that were not healthy. After the healthy eating program is carried out every day, no children are eating snacks on the roadside during the learning process. This is because, food that has been provided by the school, is also supported by parents of guardians of students who do not provide pocket money to their children. Parents and teachers alike must provide healthy food for children so that children's nutritional needs are met (Blanchette \& Brug, 2005).

To maintain the health and nutritional content of each food menu served, Al Irsyad Al Islamiyyah Purwokerto Kindergarten involves nutritionists whose task is to choose, arrange and supervise any food that will be served to children. Siti Marjiati, S. Gz., A nutritionist who works to control food served at the healthy eating program at Al Irsyad Al Islamiyyah Purwokerto Kindergarten.

The main task of a nutritionist in a healthy eating program at Al Irsyad Al Islamiyyah Purwokerto Kindergarten is to prepare a food menu to be served to children by considering the nutri- tional content. Starting from compiling the menu based on its nutritional content, selecting food ingredients that are adjusted to the specifications that have been determined, and determining how to process and monitor it. Thus, the food served in this healthy eating program will be controlled.

\section{Implementation of a Healthy Eating Program at Tk Al Irsyad Al Islamiyyah Purwokerto}

The healthy eating program at Al Irsyad Al Islamiyyah Purwokerto Kindergarten is held every Monday to Saturday at 10.00-10.30 (class A) and 10.30-11.00 (class B) WIB according to the schedule set by the school. Determination of the implementation of a healthy eating program at Al Irsyad Al Islamiyyah Purwokerto Kindergarten is based on the habits of children who do not like to eat vegetables, even though vegetables are very important for children's growth and development, thus this program is carried out every lesson, so that children will be accustomed and trained to eat healthy food every day. Vegetables and fruit are important foods that must be consumed at every meal (Pranungsari et al, 2019).

Seeing the habits of children who have difficulty eating vegetables and the present-day phenomena of unhealthy lifestyles and all instant foods, finally our kindergarten program has a program in which this program is called a healthy eating program. The healthy food program is supported by providing stimulus from parents to children related to food consumption (Triwijayati et al, 2016).

In general, very young children need balanced nutrition for maximum growth and development of children. The Al Irsyad Al Islamiyyah Purwokerto Kindergarten institute makes a breakthrough in which the child gets a balanced nutritional intake which is a healthy eating program. The first healthy eating program was held in 2003. Initially the healthy eating program was carried out once a week every Saturday. Over time and a positive response, in 2015 a healthy eating program was conducted every Monday to Saturday or every lesson was carried out, because to avoid children carrying or buying snacks they like such as junk food. Children are more accustomed to home-cooked foods such as vegetable dishes, fruits, etc. that are cooked in a healthy manner and monitored directly by nutritionists starting from selecting food ingredients, choosing menu compositions, to the way they are served.

The healthy eating program is a daily routine in the Al Irsyad Al Islamiyyah kindergarten. Because the teacher does not want to see the child carrying provisions with unhealthy foods such as 
snacks, cilok, siomay, and so on. Therefore this program is carried out every Monday to Saturday. Where this program will better help children in healthy lifestyles. Food given to Al Irsyad Al Islamiyyah Purwokerto's kindergarten children is monitored directly by nutritionists who have been provided in the Al Irsyad ring. Funded by all guardians of Al Irsyad Al Islamiyyah Purwokerto Kindergarten students.

Al Irsyad Al Islamiyyah Purwokerto Kindergarten who has quite a number of children and is divided into several classes according to age there is class A and class B. Children eat healthy in their respective classrooms. With a pleasant and uplifting atmosphere. Class A eats healthy at 10:30. Meanwhile, class B at 11:00. that time brings together lunch.

Seeing this healthy eating program, we as teachers have also realized that a lot of habits have been made by children. Such as habituating a healthy lifestyle, eating vegetables, and so on. Only from one program, namely a healthy eating program, has many benefits.

\section{CONCLUSION}

After the research conducted data collection activities, data presentation, and data analysis in a study entitled Improving Children's Nutrition through the Healthy Eating Program at AlIrsyad Al Islamiyyah Purwokerto Kindergarten, the final step was to seek to be able to answer the problem formulation sought in this study. Based on the results of data analysis, it can be presented a healthy eating program conducted at Al-Irsyad Al Islamiyyah Purwokerto Kindergarten to:

First, discussing a healthy eating program implemented at Al-Irsyad Al Islamiyyah Purwokerto Kindergarten can improve nutritional status in early childhood. Second, a healthy eating program is implemented by considering a diet prepared by a nutritionist in accordance with the nutritional needs of the child each time it is collected. In choosing food ingredients, TK Al-Irsyad Al Islamiyyah Purwokerto can tightly adjust the specifications of fruits and vegetables to be processed and consumed. Al Irsyad Al Islamiyyah Purokerto Kindergarten provides student guardians donations to process and cook food that will be served at a healthy eating program.

\section{REFERENCES}

Blanchette, L., \& Brug, J. (2005). Determinants of fruit and vegetable consumption among 6-12 year old children and effective interventions to increase consumption. Journal of human nutrition and dietetics, 18(6), 431-443.

Candrawati, E., Wiarsih, W., \& Sukihananto, S. (2014). Ketersediaan Buah dan Sayur dalam Keluarga Sebagai Strategi Intervensi Peningkatan Konsumsi Buah dan Sayur Anak Usia prasekolah. Care: Jurnal Ilmiah Ilmu Kesehatan, 2(3), 31-40.

Emzir. (2010). Qualitative Research Methodology: Data Analysis. Jakarta: Rajawali Press

Hardinsyah. (2017). Nutrition Theory and Application. EGC Medical Book Publisher.

Haryanto, V. L. (2018). 5 Causes of 2-Year-Old Children Difficult to Eat Vegetables and How to Overcome Them. Hamil.co.id.co.id. March 22, 2018. https:// hamil.co.id/anak/makanan-anak/anak-2-tahunsusah-makan-sayuran.

Hung, H. C., Joshipura, K. J., Jiang, R., Hu, F. B., Hunter, D., Smith-Warner, S. A., ... \& Willett, W. C. (2004). Fruit and vegetable intake and risk of major chronic disease. Journal of the National Cancer Institute, 96(21), 1577-1584.

Indonesian Nutrition Experts. (2016). Nutrition: Theory \& Application. Jakarta: EGC Medical Book Publisher.

Koui, E., \& Jago, R. (2008). Associations between selfreported fruit and vegetable consumption and home availability of fruit and vegetables among Greek primary-school children. Public Health $\mathrm{Nu}$ trition, 11(11), 1142-1148.

Lestari, I. D. (2012). Efforts to Habit Consuming Healthy Foods Through Variations of Healthy Snacks to Small Class Children in Milas Playgroup. Yogyakarta: Universitas Negeri Yogyakarta.

Moleong, L. J. (2013). Qualitative Research Methodology. Bandung: PT Youth Rosdakarya.

Putri, R. F., Sulastri, D., \& Lestari, Y. (2015). Faktor-Faktor yang Berhubungan dengan Status Gizi Anak Balita di Wilayah Kerja Puskesmas Nanggalo Padang. Jurnal Kesehatan Andalas, 4(1), 1-7.

Pranungsari, D., Anwar, I. C., Maarifudin, S., \& Arisandi, V. (2019). Edukasi kesehatan konsumsi sayur dan buah, serta pengelolaan sampah pada anak-anak SD Negeri Kempong. Jurnal Pemberdayaan: Publikasi Hasil Pengabdian Kepada Masyarakat, 3(2), 179-184.

Rusilanti. (2015). Preschool Children's Nutrition and Health. Bandung: Rosda Karya.

Rozaline, H., \& Sekarindah, T. (2006). Terapi Jus Buah dan Sayur. Depok: Niaga Swadaya.

Triwijayati, A., Setiyati, E. A., Setianingsih, Y., \& Luciana, M. L. (2016). Anak dan Jajanan Sekolah: Program Pemberdayaan Kesehatan Anak Sekolah dalam Perspektif Pemerintah Daerah. Media Kesehatan Masyarakat Indonesia, 12(3), 170-180.

Ulfah, E., Rahayuningsih, S. E., Herman, H., Susiarno, H., Gurnida, D. A., Gamayani, U., \& Sukandar, H. (2018). Asuhan nutrisi dan stimulasi dengan status pertumbuhan dan perkembangan balita usia $12-36$ bulan. Global Medical and Health Communication, 6(38), 12-20.

Wyse, R., Campbell, E., Nathan, N., \& Wolfenden, L. (2011). Associations between characteristics of the home food environment and fruit and vegetable intake in preschool children: a cross-sectional study. BMC Public Health, 11(1), 938. 